\title{
Quality management of interventions on historic buildings
}

\author{
N. Van Roy ${ }^{1}$, E. Verstrynge ${ }^{2} \&$ K. Van Balen ${ }^{1,3}$ \\ ${ }^{1} K U$ Leuven, Civil Engineering Department, Belgium \\ ${ }^{2} K U$ Leuven, Department of Architecture, \\ Campus Sint-Lucas Brussels and Ghent, Belgium \\ ${ }^{3} \mathrm{KU}$ Leuven, Raymond Lemaire International Centre for Conservation \\ (RLICC), Belgium
}

\begin{abstract}
The evaluation of the initial quality and long-term durability of an intervention on a historic building proves to be complex. On the one hand, technical and functional requirements can be defined which will lead to recipes and intervention methods. On the other hand, the heritage repair principles such as reversibility, compatibility and retreatability, should be respected. How are these aspects taken into account when defining an intervention in current practice? And how are they translated by the craftsmen into an actual intervention that meets their skills?

The quality management approach presented in this paper was developed specifically for the cultural heritage sector and is based on a literature study and a study of current practice within Europe. Both literature and practice demonstrate that preservation of cultural heritage can be obtained by applying a planned preventive conservation approach and through a positive collaboration of all stakeholders.

The proposed scheme will be confronted with the restoration of the fifteenth century enclosure of the Abbey of Tongerlo in order to understand its applicability in practice as a means for measuring the initial quality and long-term durability of interventions.

Keywords: quality, management approach, planned preventive conservation, repair principles, durability, performances, cultural significance.
\end{abstract}




\section{Introduction}

The cultural heritage sector is increasingly considered a driving force for economic and social growth, as a source of identity and creativity [1]. However, the sector faces some important challenges, such as the impact of the economic crisis on a mainly government-financed sector, and the impact of increasing regulations related to energy consumption and climate change. It is therefore important to safeguard the quality of interventions, but also to use quality improvement as a means for increasing the efficiency of the management of historic sites.

The complexity of interventions on historic sites and building asks for a specific approach that takes into account both the complexity of existing historic structures as well as the specificity of historic building materials and techniques. This constitutes the basis for recognizing the need to better understand the factors that in current practice are influencing the quality and durability of repair interventions in Flanders. This understanding is an important basis for developing a systematic approach for the optimization of the quality of interventions on historic buildings.

In this paper, we will first introduce how quality management for interventions on historic buildings is discussed in literature. The insights in existing quality management approaches demonstrate that two aspects can be interesting for the cultural heritage sector, namely the concepts of Total Quality Control and the principles of Lean innovation [2-4]. The results of the literature study make up the first part of the paper, whereas in the second part a state of the art is given of current practice in Europe. Finally, the results of both studies form the basis for a discussion on the appropriate quality management approach for the cultural heritage sector. The objective is the preservation of cultural significance and this is obtained by a planned preventive conservation approach and through a collaboration of all the stakeholders.

\section{Quality management of interventions on historic buildings in literature}

\subsection{Approaches in literature}

Although literature on cultural heritage focuses on values, ethics, conservation principles, management approaches and the effectiveness of interventions, it discusses the quality management of interventions mostly in the margins. For the construction sector in general however, quality has been an important issue since the 1980s. The difficulties in improving the quality of interventions was attributed to the large amount of manual labour, the difficulties in introducing automation and the fact that the sector deals with several stakeholders whom each play an important role in achieving the quality of a final product $[2,5]$. Interventions on historic buildings prove to be even more complex, since every case is unique due to the complexity of the different historical layers and the number of stakeholders involved tends to be even higher. 
Two aspects of quality management developed for other sectors are interesting for the cultural heritage sector: the concept of Total Quality Control and the principles of Lean innovation. The concept of Total Quality Control consists of developing a general awareness that every stakeholder needs to play its part in order to obtain the required quality of a product. This was one of the strengths of the Japanese model of Total Quality Control for companies, where employees did not only understand the importance of doing their job well as part of the production process, but they also continually searched for ways to improve their work and therefore also the final quality of the product and the efficiency of the production process $[2,3,5]$. The concept of Lean innovation is based on the Japanese system of Total Quality Control but it focuses on working efficiently with knowledge. Lean innovation focuses on how creative ideas and solutions can be developed in an efficient way. This means three fundamental principles should be respected. At first, the focus of the innovative process should be clear, in order to avoid over or under developing the solution. Secondly, the aim should be an optimum planning of the work process. At last, working with Lean means continually evaluating your work and making improvement [4].

\subsection{The goal and means of a quality management approach for cultural heritage}

Quality is related to a certain state or condition one wants to obtain and for the cultural heritage sector, this is the preservation of cultural significance [6-9]. For the last fifteen years, research has demonstrated that the best means to obtain this objective is planned preventive conservation. Planned preventive conservation is a well-defined process of monitoring, planning and technical actions, with the aim of preserving cultural significance [7, 9-12]. All interventions are minimal technical interventions. This means interfering as much as necessary for allowing an item to retain a state in which it can perform its required function, but as little as possible in order to avoid the unnecessary replacement of historic fabric . Some interventions consist of an actual cure of deterioration, but most interventions consist of the constant control of a chronical condition of deterioration, in order to slow down an inevitable decline $[13,14]$.

Planned preventive conservation is a management approach that achieves the preservation of cultural significance by continuous improvements of the state of conservation, rather than by 'after damage' restoration. This approach can guarantee a better preservation of cultural significance, if applied strategically, and it aims at a long term cost saving [9, 10, 13].

The management approach starts with a clear understanding of the cultural significance of a building. This definition should be constantly reviewed and updated. The state of conservation of a building is assessed by performing a condition survey. Annual inspections will review and update the condition survey and will refine the annual program of actions and interventions [7-9].

The interventions on historic buildings follow a four steps approach: anamnesis, diagnosis, therapy, controls $[15,16]$. Some repair principles should be respected. The principle of minimal intervention - doing as little as possible and 
as much as necessary - as well as the principles of compatibility, reversibility and retreatability will determine the sustainability of an intervention. Working with compatible materials will furthermore also contribute to the durability of an intervention [7, 13-15, 17-20].

To ensure that an intervention is correctly carried out, the application methodology needs to be verified during the execution. Relying only on a system of quality control during execution is however expensive and demotivates the craftsmen who feel like no trust is put in their skills [21].

The complexity of the above described management approach requires the elaboration of numerous types of information, which can be an important asset when processed and stored in an integrated information system [8].

\subsection{The important role of the stakeholders}

The concept of Total Quality Control consists of developing a general awareness that every stakeholder needs to play its part in order to obtain the expected performance of an intervention [2]. For the cultural heritage sector, the entire community is involved, since there is a strong relationship between a community and its heritage and community involvement is therefore an important asset for the improvement of quality [10].

A few stakeholders however will need to play an active role in order for an intervention to come to a good end: owners, architects and engineers, contractors and craftsmen.

For the construction sector in general, the owner plays a very important role in clearly defining his expectations, which will be combined with the existing regulations in order to determine the required performances [2]. For cultural heritage in specific, it also important that the owners understand its duty of care towards the community as well as the benefits of working with a planned management system [9].

Architects and engineers should give relevant and correct advice and they should be willing to collaborate in a management approach, even though for them this might be less interesting than a major renovation or less attractive than a major restoration [9].

The importance of workmanship in quality improvement proves to be an important factor for the construction sector in general and the cultural heritage sector in specific. Knowledge on historic materials and techniques is fading and most European countries note a shortage of properly trained and qualified contractors and craftsmen for works on historic buildings [9, 17]. A number of conditions should be fulfilled for craftsmen to play their role in obtaining expected performance for interventions on historic buildings. At first, the craftsmen need specific training and skills related to historic materials and techniques [22]. However, it is not merely a matter of operational skills, since craftsmen need to obtain also the capacity to understand the complexity of cultural heritage, which will help for them to obtain a sense of responsibility [23]. By understanding that interventions on historic buildings are asking also for the craftsmen to be creative, they will be respected and entrusted with the important task to adopt their skills 
and knowledge on historic materials and techniques for the specific case in consideration [22]. This means however an adaptation of existing training models and professional competence models for the cultural heritage sector.

\section{Quality management of interventions on historic buildings in practice}

In Flanders, responsibility for the management and maintenance of listed cultural heritage is imposed upon owners by law. Owners are asked to maintain their property by management, maintenance, protection and repair works. Management is considered insufficient when it leads to deterioration and loss of cultural significance [24]. In order to guarantee a good management of listed cultural heritage, the government foresees funding for interventions and the development of management plans, however the available funding does not meet the current demand and for the large stock of historic sites and buildings that are not listed, there is no specific funding. This is only one of the reasons for the increased understanding that instead of focusing on the restoration of single objects, we should focus on the preventive conservation of the built environment [10-12].

Preventive conservation is encouraged in Flanders, since owners of historic buildings and sites can call upon the support of Monument's Watch Flanders, who delivers regular inspection services and monitoring. Almost $30 \%$ of listed buildings in Flanders are a member of Monument's Watch. Inspection reports contain an assessment of the condition of a building and a number of recommendations for the management and maintenance of the property. The recommendations for repair works are however not always turned into practice, as was proven by an inquiry among members of Monument's Watch in 2011, mostly due to a lack of budget or planning, but often also because owners cannot find skilled craftsmen for repair works. And detailed instructions on how to perform the repairs on their own were not added to the reports [25]. This shortage of properly trained and qualified craftsmen able to undertake maintenance on historic buildings and sites exists in most European countries [9, 17]. In the UK, the National Heritage Training Group [26] sees to the continuous development of numerous training initiatives and accreditation schemes were introduced for building professionals working on grant-aided historic buildings in order to reassure customer confidence and to enhance the understanding of traditional materials and technology employed on historic buildings [9]. Also "Stichting Erkende Restauratiekwaliteit Monumentenzorg (ERM)" (Foundation for Recognized Restoration quality in Cultural Heritage) focuses in the Netherlands on the accreditation of craftsmen [27]. In order to develop an accreditation system, it is however important to understand the required competences of craftsmen for different types of interventions and the accreditation system is therefore developed in close collaboration with different stakeholders. With the same scope of improving the technical quality of interventions, "Stichting ERM" developed under the authority of the Dutch government guidelines for interventions on traditional materials with traditional techniques. During an expert meeting on 
"Restoration quality in European perspective", organized by the Dutch government in October 2014, Colm Murray of the Heritage Council (Ireland) however demonstrated the flaw in an approach that focuses only on accreditations and guidelines by addressing the specific situation of vernacular architecture in Ireland: "How can we standardize a living tradition?"

\section{Defining quality management of interventions on historic buildings: discussion}

In this part, a quality management approach for the cultural heritage sector is proposed, which is based on the principles of Lean innovation and preventive conservation, taking into account the four steps of intervention (anamnesis, diagnosis, therapy, controls). The implementation of the quality management approach should be based on the concept of Total Quality Control [2-5, 10-12, $15,16]$.

There are three dimensions to achieve efficiency through Lean innovation: outer efficiency, inner efficiency and the principle of continuous improvement, fig. 1. The outer efficiency is related to the project objectives. Well-defined project objectives are essential in order to achieve efficiency. The inner efficiency concerns the project plan, or the series of activities that will transform a need into a solution. Instead of aiming at major improvements once in a while, lean innovation will point at frequently making small improvements. This is one of the key principles of Total Quality Control and a fundamental aspect of the improvement loop or Deming loop: Plan-Do-Check-Act [4].

Quality management of interventions on historic buildings therefore starts with a well-defined management approach (outer efficiency). This approach is then translated into a management plan (inner efficiency), which leads to actions and interventions (continuous improvements) (fig. 1).

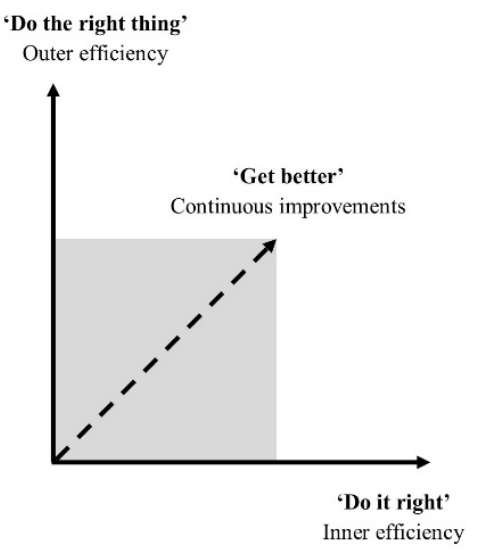

(a)

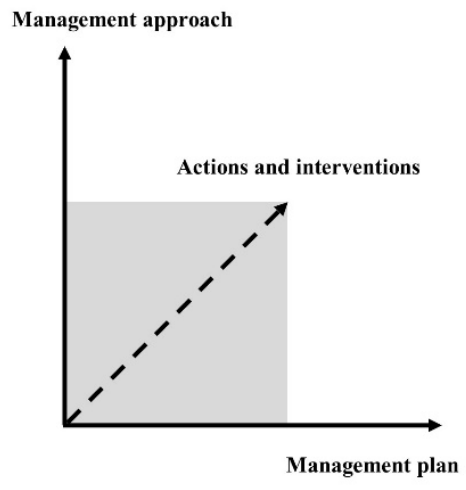

(b)

Figure 1: Translating the three dimensions of Lean innovation (a), adopted from [4], into principles of quality management (b). 
The management approach starts by defining goals and objectives. Although the general objective is the preservation of cultural heritage, for a specific building the goals should be defined in detail and they should also take into account the use of the building. Therefore, the goal of the management approach is to decide on the expected performances, a decision that should be regularly reviewed and updated.

From a technical viewpoint, there are three types of performances at three levels of detail that should be taken into account. At the level of the building, we can define functional performances, such as the drainage system. At the level of the building's structure, we can define the structural performances and at the level of the applied materials we can define technical performances (fig. 2).

The expected performances are based on an assessment of the cultural significance of the building and a detailed condition survey. The condition survey consists of an assessment of the existing performances of the building and the applied materials, as well as a risk assessment of the progress of these performances. By evaluating a building's existing condition and understanding how the state of conservation will evolve, it is possible to establish a level of expected performances that can be obtained within the available budget and timing, while respecting the assessed cultural significance.

In practice, conservation projects sometimes focus mainly on assessing the technical performances, while it remains important never to lose track of the functional performances related to the use of the building. They also need regular attention, since often loss of function leads to lack of maintenance and degradation. It is therefore possible to apply the concept of continuous improvements also for the functional performances related to the use of the building, instead of waiting until the building is in need of major improvements. If these continuous improvements are integrated in the management plan, the impact of maintaining a building's function and use up-to-date will be considerably reduced.

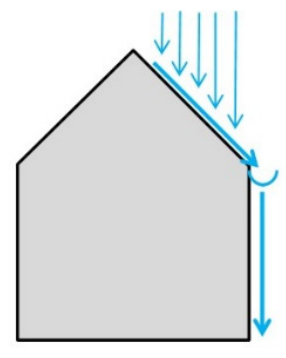

functional

performances

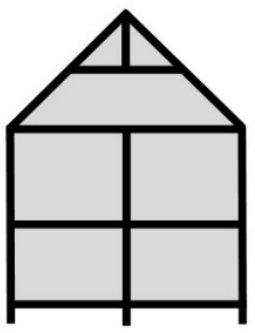

structural

performances

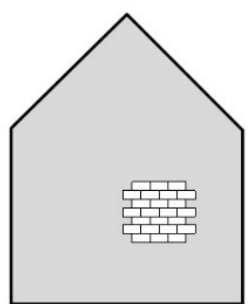

technical

performances

Figure 2: $\quad$ Performances of the building and the applied materials. 
The management plan will decide on the track that should be followed in order to achieve these objectives. An assessment of cultural significance and a detailed condition survey should be repeated regularly. In between, annual inspections will review and update the condition survey and will refine the annual program of actions and interventions. Regular evaluation of previous interventions will add to the learning process that is inherent to a management approach.

The improvement loop for interventions on historic buildings consists of four steps: anamnesis, diagnosis, therapy, controls $[15,16]$. A more detailed survey of the part of the building that is subject of an intervention will be necessary in order to investigate the causes of alterations more in detail. The existing and expected performances are defined in detail and the therapy is translated into an application procedure for the particular case in consideration.

\subsection{Research in progress}

In an initial step, the proposed scheme will be confronted with the restoration of the fifteenth century enclosure of the Abbey of Tongerlo (fig. 3), including the repair of the roofing and the wooden roof structures of three small buildings that are part of the enclosure. The project represents interventions on historic building materials (masonry repair), interventions of historic structures (timber roof structures) and interventions on the functional building requirements (drainage system). It is therefore a good case to assess the gap between the quality management approach and practice, to understand possible obstacles for the implementation of such an approach and finally to understand if the quality management approach could be a starting point for measuring the durability of a specific intervention.

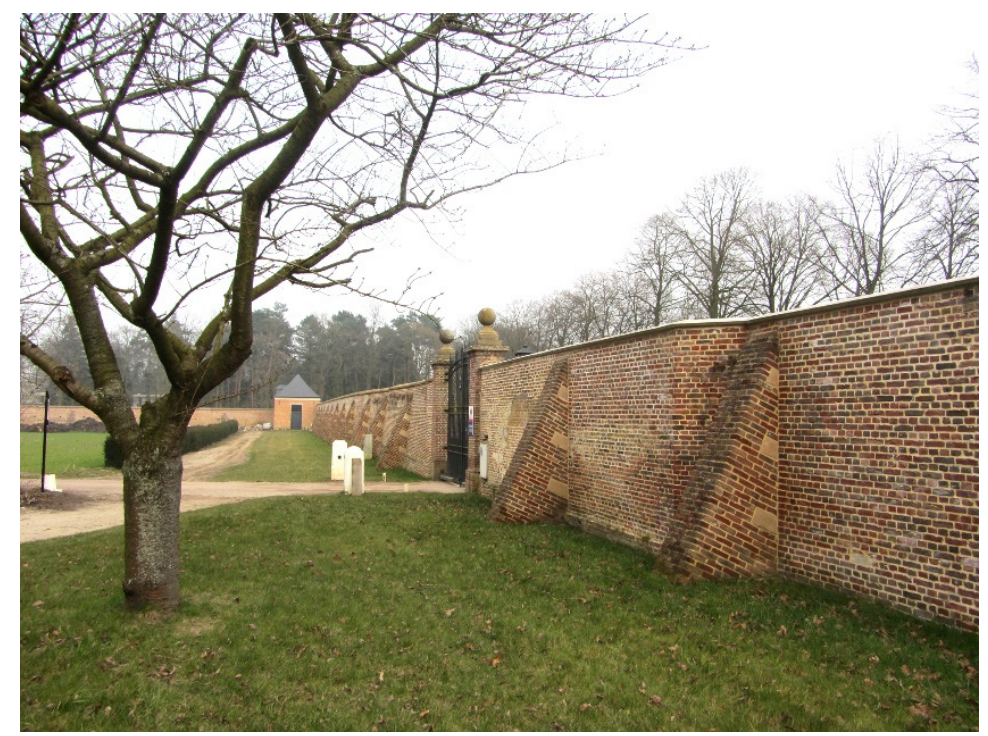

Figure 3: Enclosure of the Abbey of Tongerlo, southern part. 
Based on an interview with the owners, the management approach and the management plan applied for the historic site will be analysed and confronted with the theoretical approach proposed in this paper. A more detailed study of the restoration of the fifteenth century enclosure is based on interviews with the most important stakeholders, archive documents, pictures, drawings, invoices and a detailed analysis of the structures and materials (state of conservation and traces of previous interventions). The scope of this study is to understand why and how specific interventions were executed, in order to understand how quality control is taken into consideration in practice.

\section{Conclusions}

A study of quality management in literature and current practice lead to the development of an approach for the quality management of interventions on historic buildings. The management approach is based on planned preventive conservation and it consists of the definition of objectives - expected performances - based on a thorough assessment of the cultural significance, the state of conservation and the expected progress of existing performances. A management plan will outline which actions and interventions should be undertaken at what point in time in order to achieve the objectives. The focus lies on small improvements that consist of four steps: anamnesis, diagnosis, therapy, controls. Both literature and current practice demonstrate the important role of the stakeholders and their collaboration.

By, in an initial step, confronting this scheme with the restoration of the fifteenth century enclosure of the Abbey of Tongerlo, the approach will be refined and tailored for its further application in practice. The assessment and refinement of the approach will continue for other cases in a next step of the research in order to develop a realistic tool for the assessment of the initial quality and long-term durability of interventions in practice.

Further research is required in order to understand how to predict the progress of existing performances for historic building materials. At the level of the interventions, the study of cases will contribute to a more detailed understanding on how to define the expected performances and how to describe the application methodology in relation to these performances. A study of current practice will contribute to define how to verify the application methodology during the execution and how to implement the concept of Total Quality Control among the stakeholders, encouraging them to collaborate as partners with a common goal: the preservation of a common cultural significance.

\section{Acknowledgement}

The results presented in this paper are part of an ongoing research project funded by a Ph.D. grant of the Agency for Innovation by Science and Technology (IWT). 


\section{References}

[1] European Commission, Mapping of Cultural Heritage actions in European Union policies, programmes and activities, 2014, available online: http://ec.europa.eu/culture/library/reports/2014-heritage-mapping_en.pdf, last accessed on 7 April 2015.

[2] Cnudde, M., Kwaliteit, waarborg voor de bouwnijverheid (E: Quality, safeguard for the construction industry), WTCB tijdschrift, 2, pp. 2-13, 1984.

[3] Chiarini, A., From Total Quality Control to Lean Six Sigma, SpringerVerlag: Milan, Heidelberg, New York, Dordrecht and London, pp. 1-21, 2012.

[4] Sehested, C. \& Sonnenberg, H., Lean Innovation, A fast path from knowledge to value, Springer-Verlag: Berlin and Heidelberg, pp. 3-57, 2011.

[5] Arditi, D., Construction Quality Management: Principles and Practice, Construction Management and Economics, 30(6), pp. 500-501, 2012.

[6] International Council on Monuments and Sites (Icomos), The Burra Charter, 1999 (adopted 2013), available online: http://australia.icomos.org/ wp-content/uploads/The-Burra-Charter-2013-Adopted-31.10.2013.pdf, last accessed on 7 April 2015.

[7] Dann, N., Worthing, D. \& Bond, S., Conservation maintenance management - establishing a research agenda, Structural Survey, 17(3), pp. 143-153, 1999.

[8] Dann, N. \& Wood, S., Tensions and omissions in maintenance management advice for historic buildings, Structural Survey, 22(3), pp. 138-147, 2004.

[9] Forster, A.M. \& Kayan, B., Maintenance for historic buildings: A current perspective, Structural Survey, 27(3), pp. 210-229, 2009.

[10] Della Torre, S., Shaping Tools for Built Heritage Conservation: from Architectural Design to Program and Management, Community involvement in heritage, eds. K. Van Balen \& A. Vandesande, Garant Uitgevers: Antwerp and Apeldoorn, pp. 93-101, 2015.

[11] Van Balen, K., Preventive Conservation in the International context of the $\mathrm{PRECOM}^{3} \mathrm{Os}$ network, Proceedings of the International Conference on Preventive Conservation of Architectural Heritage, eds. Southeast University: Nanjing (China), pp. 1-13, 2011.

[12] Van Balen, K. \& Vandesande, A., (eds). Reflections on Preventive Conservation, Maintenance and Monitoring of Monuments and Sites by the PRECOM ${ }^{3}$ OS UNESCO Chair, ACCO: Leuven and Den Haag, 2013.

[13] Gasparoli, P., La manutenzione preventiva e programmata del patrimonio storico tutelato come prima forma di valorizzazione (E: Planned preventive maintenance as a first form of valorisation for the preservation of historic heritage sites), Techne, 3, pp. 148-157, 2011.

[14] Brereton, C., The repair of historic buildings: advice on principles and methods, English Heritage: London, 1995. 
[15] Van Balen, K., Stabiliteitsherstel in monumentenzorg (E: Structural consolidation in monument conservation), Stable-Unstable? Structural consolidation of ancient buildings, eds. R.M. Lemaire \& K. Van Balen, Leuven University Press: Leuven. pp. 15-27, 1988.

[16] International Council on Monuments and Sites (Icomos), Principles for the analysis, conservation and structural restoration of architectural heritage, 2003, available online: http://www.international.icomos.org/charters /structures_e.pdf, last accessed on 7 April 2015.

[17] Feilden, B.M., Conservation of Historic Buildings, ButterworthHeinemann: Oxford, 2005.

[18] Sasse, H.R. \& Snethlage, R., Methods for the Evaluation of Stone Conservation Treatment (Chapter 12), Dahlem Workshop on Saving Our Architectural Heritage: The Conservation of Historic Stone Structures, eds. N.S. Baer \& R. Snethlage, John Wiley \& Sons: Berlin. pp. 223-245, 1996.

[19] Teutonico, J.M., et al., Group Report: How Can We Ensure the Responsible and Effective Use of Treatments (Cleaning, Consolidation, Protection)? (Chapter 16), Dahlem Workshop on Saving Our Architectural Heritage: The Conservation of Historic Stone Structures, eds. N.S. Baer \& R. Snethlage, John Wiley \& Sons: Berlin, pp. 293-315, 1996.

[20] Dann, N., Hills, S. \& Worthing, D., Assessing how organizations approach the maintenance management of listed buildings, Construction Management and Economics, 24(1), pp. 97-104, 2006.

[21] Charola, A.E., De Witte, E. \& Laurenzi Tabasso, M., Establishing International Standards for the Quality Control of Conservation Materials and for Qualifying Practitioners Applying Them (Chapter 13), Dahlem Workshop on Saving Our Architectural Heritage: The Conservation of Historic Stone Structures, eds. N.S. Baer \& R. Snethlage, John Wiley \& Sons: Berlin. pp. 245-255, 1996.

[22] Van Balen, K., From conservation principles to materialization (Or the other way around: how is materialization guided by principles?), Proc. of the WTA conference on Authenticity in the restoration of monuments, ed. D. Van Gemert, WTA: Leuven, pp. 53-59, 2003.

[23] Bossi, S., Construction History: What kind of knowledge in the maintenance process?, Proc. of the Third International Congress on Construction History, Cottbus, 2009.

[24] Onroerenderfgoeddecreet (Flemish Decree for cultural heritage), 2013, available online: http://codex.vlaanderen.be/Portals/Codex/documenten/ 1023317.html, last accessed on 7 April 2015.

[25] Monumentenwacht Vlaanderen, Tevredenheidsenquête 20 jaar Monumentenwacht (E: Inquiry on clients' satisfaction 20 years Monument's Watch Flanders), 2011, available online: http://www.monumentenwacht.be/sites/www.monumentenwacht.be/files/ news/tevredenheidsenquete.pdf, last accessed on 7 April 2015. 
324 Structural Studies, Repairs and Maintenance of Heritage Architecture XIV

[26] The National Heritage Training Group (NHTG), Derbyshire, UK, http://www.the-nhtg.org.uk/, last accessed on 7 April 2015.

[27] Stichting Erkende Restauratiekwaliteit Monumentenzorg (ERM), Gouda, The Netherlands, http://www.stichtingerm.nl/, last accessed on 7 April 2015. 